\title{
Identifying consumer review through web design and online advertisement in online shop
}

\author{
Ariani Kusumo Wardhani ${ }^{a^{*}}$
}

${ }^{a}$ Universitas Mercu Buana, Indonesia

\section{CH R O N I C L E}

Article history:

Received: May 20, 2020

Received in revised format: May

29, 2020

Accepted: June 9, 2020

Available online: June 9, 2020

Keywords:

Consumer Review

Web Design

E-WOM

Online Advertisement

Purchase Intention \begin{abstract}
A B S T R A C T
Several studies in the past have reviewed numerous factors that become the consideration of the customers in performing transactions through online sites. In this study, the researcher investigates whether consumer review, web design and online advertisement variables are important for customers in performing transaction through e-commerce. The results of the study contribute for the providers of the online shopping sites in defining the future strategies. At the same time, the results of the study are also expected to provide contributions for the future studies that focus on the ecommerce from the perspective of consumer review, web design and online advertisement. Furthermore, in analyzing the respondents' characteristics the researcher runs the SPSS Software and for analyzing the data the researcher runs the PLS 3.0. Then, the survey technique in the form of questionnaire distribution implemented toward the respondents who used to perform transactions through online shopping sites. The research finds that consumer review, web design and online advertisement influence on online purchase intention.
\end{abstract}

\section{Introduction}

The development of Digital Era that has entered Indonesia recently has shifted the society behaviors in performing purchase decisions. At the beginning, the Indonesian people performed their purchase in the conventional shops (the offline shops) and nowadays they have performed their purchase in the e-commerce (the online shops). Based on the results of the survey by APJII in 2018, the use of Internet in the domain of Economics, especially with regards to the online purchase, has been $32.19 \%$. This percentage will be increasing, recalling the fact that Indonesia is predicted to be one of the Asian countries that have high rate of e-commerce development potentials. According to Nielsen in the report entitled Indonesia Online Shopping Outlook 2014, Indonesian customers have started to like online shopping activities; they like reading online consumer review and looking for the information about the demanded product and service. Online consumer review is a form of electronic word of mouth (e-WOM) that refers to the user-generated contents posted in both the online sites and the third-party websites. Then, according to the data from Bright Local in the report entitled Local Consumer Review Survey 2016, approximately $84 \%$ people trust the reviews provided by the customers who have experienced using certain products (Lukito \& Ikhsan, 2020).

Online consumer review (OCR) has significant impact on purchase intention. The results of a study by Kiran and Vasantha (2015) show that the reviews are influenced by the awareness, the belief and the attitude of the customers. In addition, Kiran and Vasantha (2015) also propose that shopping environment has strong relationship to online consumer review and plays the main role of electronic word of mouth (e-WOM). Useful information that has been provided for a product might decrease the 
risk that the customers perceive and increase the purchase intention. The influence of online consumer review (OCR) is a highly significant issue for the purchase intention before the customers finally commit their purchase decision (Elwalda \& $\mathrm{Lu}, 2014)$. The high number of online consumer reviews shows the quality and the popularity of the product and therefore the high number of online consumer reviews might increase the purchase intention of the customers (Obiedat, 2013). In relation to online consumer review, advertisement is part of modern industrial life. advertisement is a form of message that has been delivered to the public by means of a medium. Similarly, online advertisement is a form of promotion that benefits the Internet for delivering marketing messages in order to draw the customer intention (Aqsa, 2017). Online advertisement plays highly significant role in product placement and purchase intention increase (Padival \& Kenneth, 2017). The advertisement might be benefitted effectively for developing long-term impression of both the product and the company and might also trigger the immediate purchase (Putra, 2017). Furthermore, web design has highly significant role in developing purchase intention. Good web design will increase the purchase intention of the customers (Ali, 2016), while well-qualified website might influence the customer trust toward the agent since purchase intention is influenced by customer trust and customer perspective on the usefulness of the website (Octavia \& Tamerlane, 2017; Al-Qudah, 2020; Ahmad et al., 2020; Aji et al., 2020).

Within e-commerce, website is a medium of interaction between the buyers and the sellers because the purchase and sell process does not take place in a direct manner but in online manner through Internet. The implication is that the website that has been displayed should be able to describe the product that has been sold appropriately and should also be able to provide clear information to the customers. Departing from the above elaboration, the researcher would like to conduct a study that will focus on the influence of consumer review, web design and online advertisement on purchase intention of online site customers.

\section{Literature review and hypothesis development}

\subsection{E-Marketplace}

E-marketplace is part of E-commerce. In relation to the statement, Sadgotra and Putra (2013) explain that online shop refers to all efforts that have been pursued in order to market a product or a service through or by using Internet or www-network as the medium while the term place refers to a certain location. Therefore, it might be concluded that E-marketplace is a place or an institution for pursuing the product or service marketing activities by means of Internet as the medium. E-marketplace alone is an inter-organization system in which buyers and sellers in the market communicate information about price and product and settle their transaction through electronic communication (Marco \& Ningrum, 2017; Alshare et al., 2020). Emarketplace thus might be considered as the second wave in E-commerce and as an expansion from the combination of consumer business (BSB, C2B and $\mathrm{C} 2 \mathrm{C}$ ) within the framework of B2B. The main offer of E-marketplace lies in the efforts of putting together the buyers and the sellers in accordance to their needs and offering transaction efficiency

\subsection{Online Consumer Review (OCR)}

Online consumer review is one of the electronic words of mouth (e-WOM) forms. Khammash (2008) explains that online consumer review might be understood as one of the media for reviewing the product, the company service and the producer company from one customer to another. Similarly, Auliya, Umam \& Prastiwi (2017) state that online consumer review (OCR) is a review toward a product that has been provided by the customers who purchase or consume the product and who have experience with a product or a service. On the other hand, Mudambi and Schuff (2010) state that online review from the customers might be implied as the results of product evaluation that has been downloaded from the company website or the third-party website. As having been implied, online consumer review is one of the electronic words of mouth (e-WOM) forms. The electronic words of mouth (e-WOM) itself is defined as the positive statement or the positive criteria that have been stated by the people who will purchase a product, the people who have purchased a product or the people who would like provide overall comment toward a product.

\subsection{Web Design}

According to Arief (2011), website is one of the applications that contain multimedia documents (texts, pictures, animations and videos) inside the protocol HTTP (Hyper Text Transfer Protocol) that should be accessed through software known as browser. Another definition according to the standards of ISO 8402 states that website refers to the overall features and characteristics of the product software that support the capacity to satisfy the desired needs. On the other hand, Tjiptono (2013) defines quality as the computability for fitness. Last but not the least, Habibi et al. (2014) state that web design refers to the measures of website strength based on the user evaluation on the features that meet the consumer needs.

\subsection{Online Advertisement}

Advertisement is a type of marketing communication, which has been a general term that refers to all types of communication techniques that have been implemented by the marketers to reach their customers and deliver their message (Moriarty, Mitchell \& William, 2017). On the other hand, Kotler \& Armstrong (2012, 2013) state that advertisement refers to all types of idea, product or service presentation and promotion under non-personal manner by a certain sponsor that needs payment. 


\subsection{Hypothesis Development}

After gathering the theories that might support the conduct of the study, the researcher would like to define the hypotheses that will be further investigated within the study. These hypotheses are proposed in relation to the topic of the study and also the theories that have been reviewed within the study. Thus, the hypotheses might be consulted in the following section.

\section{The Influence of Online Consumer review (OCR) on Online Purchase Intention}

Online consumer review (OCR) has been highly significant and influential part on the purchase behavior for the web-oriented customers. In other words, online consumer review (OCR) has huge impact on the purchase intention. According to Kiran \& Vasantha (2015), the results of a consumer review is influenced by the awareness, the belief and the attitude of the customers. In addition, Kiran \& Vasantha (2015) state that work environment has strong relationship to the online consumer review and becomes the man role of the electronic words of mouth (e-WOM). The influence of online consumer review (OCR) thus becomes a highly significant issue for the purchase intention before the consumers finally commit their purchase decision (Elwalda \& Lu, 2014). Therefore, online consumer review might serve as a direct source of information mainly toward the products that will be purchased. In the same time, the review and the rating from the customers might provide more accurate and emotional assessment because the review has been provided by the fellow consumers and consequently the review has higher trust value (Farki, Baihaqi \& Wibawa, 2016). The high number of online consumer review shows the quality and the popularity of a product and, therefore, improves the purchase intention among the consumers (Obiedat, 2013). Departing from this elaboration, the researcher would like to propose the first problem formulation as follows:

$\mathbf{H}_{1}$ : Online Consumer Review (OCR) has positive and significant influence on Online Purchase Intention.

\section{The Influence of Web Design on Online Purchase Intention}

Web design has very crucial role in developing the purchase intention. A good web design will increase the purchase intention of the customers (Ali, 2016). Furthermore, a well-qualified web design might influence the customers' trust toward the agent. In other words, purchase intention is influenced by the trust and the perspective of the customers toward the usefulness of a web site (Octavia \& Tamerlane, 2017). Departing from this elaboration, the researcher would like to propose the second problem formulation as follows:

H2: Web Design has positive and significant influence on Online Purchase Intention.

\section{The Influence of Online Advertisement on Online Purchase Intention}

Online advertisement is a form of promotion that benefits the Internet for delivering the marketing messages in order to draw the potential customers. Online advertisement plays very crucial role within the placement of a product (Padival \& Kenneth, 2017). Advertisement might provide visual stimulus to the message retrievers so that the message retrievers, or specifically the customers, will have intention to purchase a product or a service (Rachmadhania \& Pangestuti, 2017). Online advertisement is a valuable source of information about the product features and about the promotion that customers might view so that the purchase intention can be made of (Bataineh, 2015; Brahim, 2016). Online advertisement offers a number of opportunities for improving the purchase behavior (Zourikalatehsamad, Payambarpour, Alwashali \& Abdolkarimi, 2015). Departing from this elaboration, the researcher would like to propose the third hypothesis as follows:

H3: Online Advertisement has positive and significant influence on Online Purchase Intention.

\subsection{Research Framework}

Based on the theories that have been reviewed and also the hypotheses that have been proposed, the researcher framework for the conduct of the study might be defined as follows:

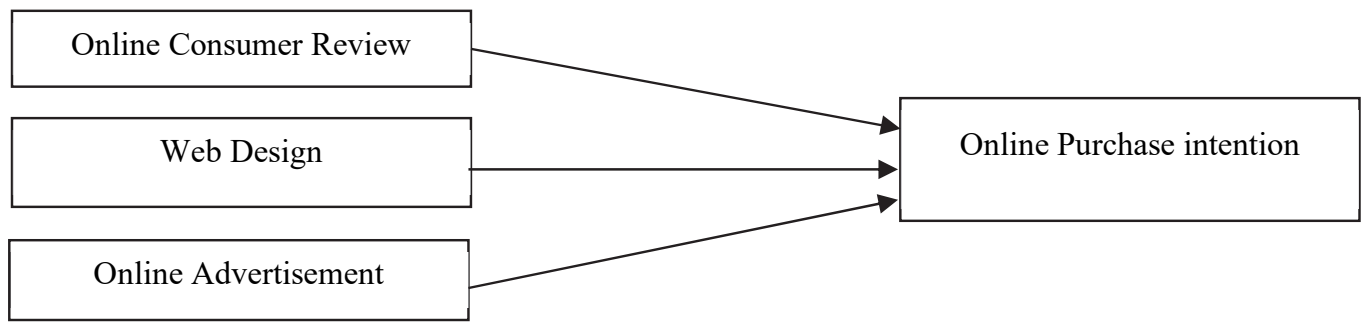

Fig. 1. Research Framework 


\section{Research Methodology}

The Component/Variance-Based Structural Equation Modelling is an alternative of the Covariance-Based Structural Equation Modelling. This Component/Variance-Based Structural Equation Modelling is also known as Partial Least Square (PLS). This method is intended to perform the causal-predictive analysis within the situations of high complexity and low theoretical support. In line with the intention, the aim of PLS is to find the predictive linear variable among the variables (the componentbased predictive model) (Ghozali, 2014). The procedures that should be proposed for meeting the assumptions of the variancebased SEM become the guidelines for the variance-based SEM modelling both within the data gathering process and within the data processing by means of Smart PLS 3. The Component/Variance-Based Structural Equation Modelling is an alternative of the Covariance-Based Structural Equation Modelling. This Component/Variance-Based Structural Equation Modelling is also known as Partial Least Square (PLS). This method is intended to perform the causal-predictive analysis within the situations of high complexity and low theoretical support. In line with the intention, the aim of PLS is to find the predictive linear variable among the variables (the component-based predictive model) (Ghozali, 2014). The procedures that should be proposed for meeting the assumptions of the variance-based SEM become the guidelines for the variance-based SEM modelling both within the data gathering process and within the data processing by means of Smart PLS 3.

\subsection{Measurement Model}

\section{Convergent Validity}

The convergent validity test of the measurement model with the reflexive indicators is assessed based on the correlation between the item score/component score and the construct score that has been calculated by using the PLS. The individual indicators will be considered valid if the correlation value is higher than 0.70 .

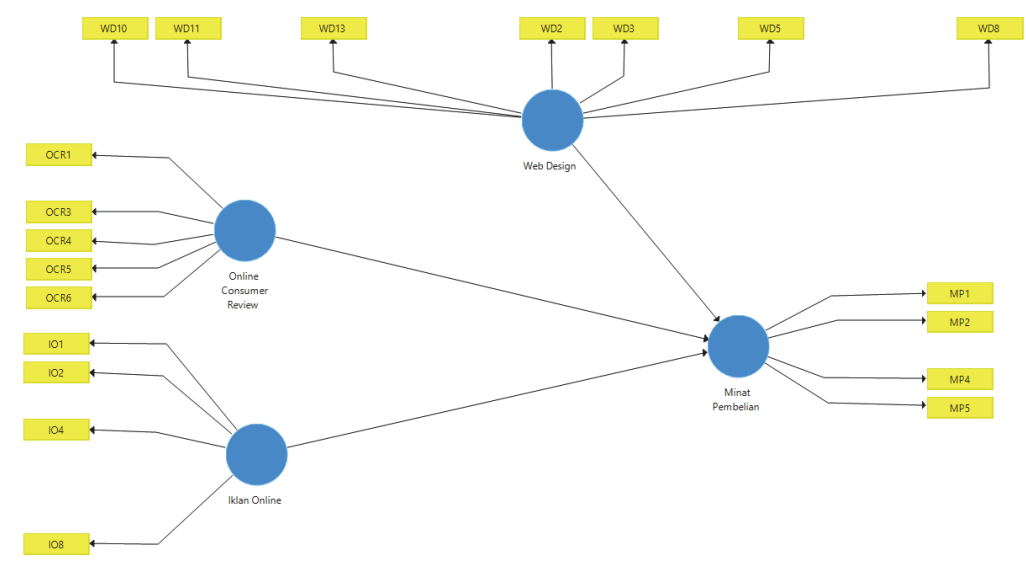

Fig. 2. Results of PLS Algorithm

\section{Discriminant Validity}

For the conduct of the discriminant validity test, the reflexive indicators might be consulted on the cross-loading value between the indicators and the constructs. An indicator is considered valid if the value of the loading factor is the highest relative to the targeted construct in comparison to the loading factor value of the other construct. Thereby, the latent constructs are able to predict the indicators in their own block better than the indicators in the other block.

Table 1

Result of AVE

\begin{tabular}{lc}
\hline & Average Variance Extracted (AVE) \\
\hline Online Advertisement & 0.993 \\
Purchase Intention & 0.625 \\
Online Consumer Review & 0.894 \\
Web Design & 0.761 \\
\hline
\end{tabular}

Table 2

Results of Discriminant Validity Test (Fornell Lacker Criterum)

\begin{tabular}{lccc}
\hline & Online Advertisement & Purchase Intention & Online Consumer Review \\
\hline Online Advertisement & $\mathbf{0 . 9 9 7}$ & & \\
Purchase Intention & 0.498 & $\mathbf{0 . 7 9 1}$ & \\
Online Consumer Review & 0.283 & 0.596 & $\mathbf{0 . 9 4 5}$ \\
Web Design & 0.371 & 0.779 & 0.6 \\
\hline
\end{tabular}


From the results in Table 1 and Table 2, it might be concluded that the square root of the Average Variance Extracted (AVE) for each construct has been higher than the correlation value between one construct and another within the model. From the AVE Value, it might be concluded that the construct within the model that has been estimated already meets the discriminant validity criteria.

\section{Composite Reliability}

The composite reliability test aim at testing the reliability of the instrument within a research model or at measuring the internal consistency. The value of the composite reliability and Cronbach's alpha test should be higher than 0.60 . If all of the latent variables have the both the composite reliability test score and the Cronbach's alpha test score that has been equal to or higher than $0.70(\geq 0.70)$ then the indication will be that the constructs have good reliability or the questionnaire that has been implemented as the data gathering tool in the study has been reliable or consistent.

Table 3

Results of Composite Reliability

\begin{tabular}{ll}
\hline & Composite Reliability \\
\hline Online Advertisement & 0.998 \\
Purchase Intention & 0.868 \\
Online Consumer Review & 0.977 \\
Web Design & 0.957 \\
\hline
\end{tabular}

Based on the results in Table 3, it is apparent that the composite reliability test has shown satisfying results since the composite reliability value of all latent variables have been equal to or higher than $0.70(\geq 0.70)$.

\section{Structural Model}

The inner model measurement or the inner model test refers to the development of the concept and theory-based model in order to analyze the relationship between the exogenous variable and the endogenous variable that has been elaborated in the conceptual framework. The stage in the inner model test, or also known as the structural model test, consists of the procedures that will be elaborated below.

\section{Table 4}

$\mathrm{R}^{2}$ Value of the Endogenous Variable

R Square

Purchase Intention

\subsection{8}

Structural models, indicate that the model on the purchase decision variable can be said to be strong, because it has a value above 0.67 . The model of the influence of latent independent variables (online advertising, online consumer review, and web design) on purchasing intention gives an R-Square value of 0.678 which can be interpreted that the constructability variability of online advertising, online consumer review, and web design is $67.8 \%$; while the remaining $32.2 \%$ can be explained by other variables outside the study.

\section{Goodness of Fit Model}

The Goodness of Structural Model test in the Inner Model Measurement makes use of the Predictive-Relevance $\left(Q^{2}\right)$ value. The Q-Square Value that has been higher than 0 (zero) shows that the model has the predictive-relevance value. The R-Square Value of each endogenous variable in the study might be viewed in the following calculation:

$$
Q^{2}=V R^{2} \times A V E=V 0.678 \times 0.818=0.744 .
$$

The result of the above calculation shows that the Predictive-Relevance Value has been $0.744(>0.000)$. The implication of the value is that $74.4 \%$ variance on the variable Consumer Review might be explained by the variables that had been used. Thereby, the model has been considered fit for attaining the relevant predictive value.

\section{Hypothesis Test (Path Coefficient)}

The estimates value for the path relationship in the structural model should be significant. The significant value might be attained by using the bootstrapping procedures. The significance value in the hypothesis might be viewed by looking at the parameter coefficient value and the T-statistics significance value in the algorithm bootstrapping report. In order to identify whether the estimates value is significant or insignificant, the T-table at alpha $0.05(5 \%)=1.96$ might be used. Then, the $\mathrm{T}$ table value should be compared to the T-count value (T-statistics). The figure below shows that the result of structural model. 


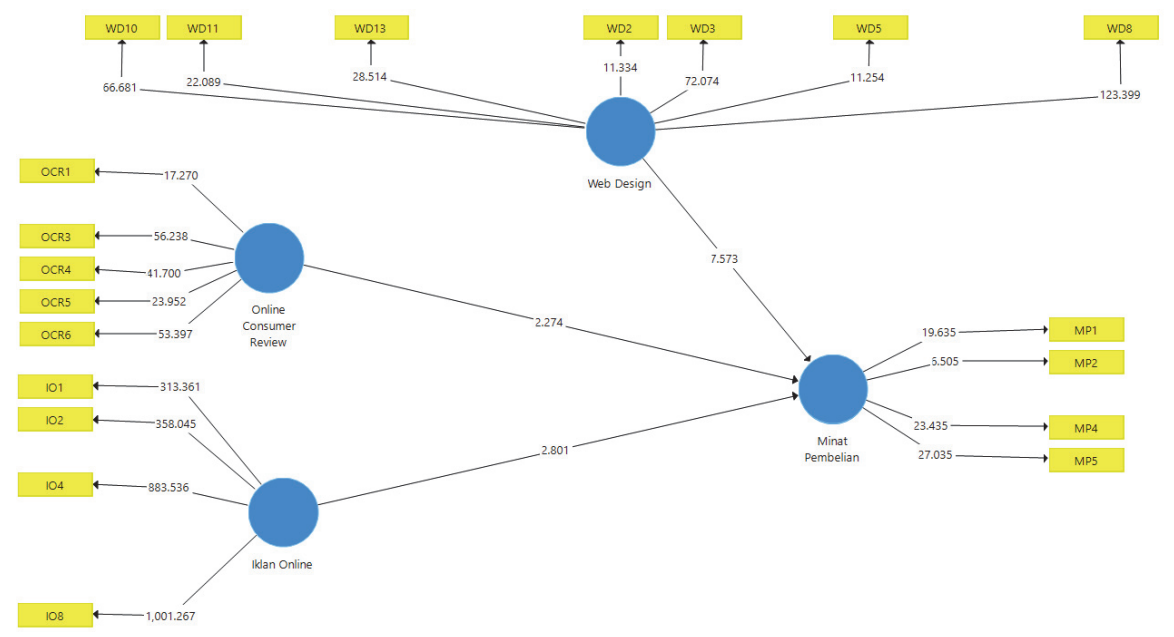

Fig. 3. Structural Model

According to Fig. 3, all the predictor variables have positive and significant impact on purchasing decision. The conclusion of the result of hypothesis testing explains on the Table 5 below:

Table 5

Results of Hypothesis

\begin{tabular}{crrrc}
\hline & Original Sample $(\mathrm{O})$ & Standard Deviation $($ STDEV) & T Statistics & Result \\
\hline $\mathrm{IO} \rightarrow \mathrm{MP}$ & 0.23 & 0.082 & 2.801 & Positive $\rightarrow$ Significant \\
$\mathrm{OCR} \rightarrow \mathrm{MP}$ & 0.179 & 0.079 & 2.274 & Positive $\rightarrow$ Significant \\
$\mathrm{WD} \rightarrow \mathrm{MP}$ & 0.586 & 0.077 & 7.573 & Positive $\rightarrow$ Significant
\end{tabular}

Based on the hypothesis test above shows that all the hypothesis are accepted, it is proved by all the value of $\mathrm{T}$ value greater than 1.96 .

\section{Discussion}

The first hypothesis (H1) states that there is a positive and significant influence in the relationship between online consumer review on purchasing intention is significant with a t-statistic value of 2,274 ( $>1.96)$. The positive path coefficient shows a direct relationship, which proves that respondents would be intentioned in shopping at Elevenia because of a reliable online consumer review. So that the online consumer review can be used as a reference by respondents before making a purchase at Elevenia. The results of this research are in accordance with and in line with research conducted by Farki, Baihaqi, and Wibawa (2016) which states that there is a positive and significant relationship between online consumer reviews of buying intention. Sondakh, Saerang, Rumokoy (2016) also conducted a study which stated that there was a positive and significant influence between online consumer reviews on buying intention. In other words, if related to previous research, it can be said to be consistent. The second hypothesis (H2) states that there is a positive and insignificant influence in the relationship between online advertising to purchase interest is not significant with a t-statistic value of $2.801(<1.96)$. The positive path coefficient shows a direct relationship. Thus, the results in this study which state that there is a positive and insignificant relationship between online advertising and purchase interest can be explained based on the statement that has the highest average index value, "I feel Elevenia's online advertising can lead to a desire to visit Elevenia's website" and "I feel that Elevenia's online advertising can generate interest in buying" can lead to the desire of consumers to search for products on the Elevenia website. Based on the significance value, it is considered insufficient to produce a consumer action that by visiting the Elevenia website, it can increase the interest of consumers to make purchases at Elevenia. The results of this research are different from research conducted by Aqsa (2017) which found that online advertising has a positive and significant effect on buying interest. The results of this study also reinforce research conducted by Setiawaty (2017) which states that there is a positive and insignificant relationship between online advertising and purchase intention.

The third hypothesis (H3) states that there is a positive and significant influence in the relationship between web design on purchasing interest is significant with a t-statistic value of $7.573(>1.96)$. The positive path coefficient value indicates a direct relationship, this proves that respondents will generate interest in shopping at Elevenia because of the good quality of the website. This can be explained by statements that have the highest average index value, "I find it easy to find the items I want on the Elevenia website" and "I feel the Elevenia website provides information in accordance with what is needed by consumers" so that respondents feel interested in making a purchase because of the ease felt by respondents in finding the desired 
item, accompanied by the information needed by users on the Elevenia website, so with that consumers feel attracted to make transactions at Elevenia. This means Elevenia has made it easy for consumers to search for products accompanied by clear information. The results of this research are in accordance with and in line with research conducted by Shahnaz and Wahyono (2016) which states that there is a positive and significant relationship between website quality and purchasing interest. Octavia and Tamerlane (2017) also conducted a study which stated that there was a significant positive effect between website quality on consumer behavior attitudes on E-commerce. In other words, if related to previous research, it can be said to be consistent.

\section{Recommendation}

The quality of the website in this study has the greatest correlation value to purchase interest in Elevenia. Thus, the quality of the website becomes the main suggestion in this study. The indicator in the quality of a website that has the lowest value is trust. In this case Elevenia is expected to be able to provide accurate information in the future so that the products that consumers receive are in accordance with the information displayed on the website. While the usability indicator has the highest value in Elevenia's website quality, this must be maintained by Elevenia. In the online consumer review variable, the lowest indicator is credibility. Elevenia is expected to provide improvements in terms of the quality of products sold and service quality so that online consumer review that is spread related to shopping at Elevenia can be trusted and used as a reference for potential consumers who are interested in shopping at Elevenia. On the online advertising variable which has the lowest significance value among other variables, Elevenia is expected to create more innovative advertising content and attract the attention of consumers so that it can stimulate consumers to visit Elevenia's website. Suggestions for further research, this research can be used as additional information, knowledge and can also be used as a reference for further research. And there are still many other variables outside this research that can influence buying interest, such as price, product quality, trust, and sales promotion.

\section{References}

Aji, P., Nadhila, V., \& Sanny, L. (2020). Effect of social media marketing on Instagram towards purchase intention: Evidence from Indonesia's ready-to-drink tea industry. International Journal of Data and Network Science, 4(2), 91-104.

Ali, F. (2016). Hotel website quality, perceived flow, customer satisfaction and purchase intention. Journal of Hospitality and Tourism Technology, 7(2), 213-228.

Al-Qudah, O. (2020). The effect of brands' social network content quality and interactivity on purchase intention: Evidence from Jordan. Management Science Letters, 10(13), 3135-3142.

Alshare, F., Aljawarneh, N., Alomari, K., Alomari, Z., Albdareen, R., AAlwagfi, A., \& Alradaideh, A. (2020). Factors influencing cellular device purchase decisions in Jordan. Management Science Letters, 10(11), 2501-2506.

Ahmad, A., Abuhashesh, M., Obeidat, Z., \& AlKhatib, M. (2020). E-WOM and airline e-ticket purchasing intention: Mediating effect of online passenger trust. Management Science Letters, 10(12), 2729-2740.

APJII (Asosiasi Penyelenggara Jasa Internet Indonesia). (2017). Survey Penetrasi dan Perilaku Pengguna Internet Indonesia. Retrieved from https://www.apjii.or.id.

Apriadi, D., \& Saputra, A. Y. (2017). E-commerce Berbasis Marketplace Dalam Upaya Mempersingkat Distribusi Penjualan Hasil Pertanian. Jurnal RESTI (Rekayasa Sistem Dan Teknologi Informasi), 1(2), 131- 136.

Aqsa, M. (2017). Pengaruh Iklan Online Terhadap Sikap Dan Minat Beli Konsumen Secara Online Di Kota Palopo (Survei pada Pengguna Internet di Kota Palopo). Prosiding Seminar Nasional, 03(1), 82-93.

Arief, M. R. (2011). Pemograman Web Dinamis menggunakan PHP dan MySQL. Yogyakarta: ANDI.

Auliya, Z. F., Umam, M. R. K., \& Prastiwi, S. K. (2017). Online Costumer Reviews ( OTRs ) dan Rating : Kekuatan Baru pada Pemasaran Online di Indonesia Online Costumer Reviews ( OTRs ) dan Rating: New Era in Indonesia Online Marketing. Ebbank, 8(1), 89-98.

Padival, A., \& Kenneth, L.M. (2017). Web advertisement: The factors influencing. International Journal of Management and Applied Science, 3(3), 38-40.

Bataineh, A. Q. (2015). The impact of perceived e-WOM on purchase intention: The mediating role of corporate image. International Journal of Marketing Studies, 7(1), 126.

Brahim, S. B. (2016). The impact of online advertising on Tunisian consumers' purchase intention. Journal of Marketing Research \& Case Studies, 2016(2016), 1-13.

Elwalda, A., \& Lu, K. (2014). The Influence of Online Customer Reviews on Purchase Intention: the Role of Non-numerical Factors. Proceedings of the LCBR European Marketing Conference, (December 2015), 1-13.

Farki, A. (2016). Pengaruh online customer review dan rating terhadap kepercayaan dan minat pembelian pada online marketplace di Indonesia (Doctoral dissertation, Institut Teknology Sepuluh Nopember.

Ghozali, I. (2014). Structural Equation Modelling Metode Alternatif dengan Partial Least Square (PLS). Edisi 4. Semarang: Badan Penerbit Universitas Diponegoro.

Habibi, A., Hagh, S. G., Bahabadi, M. H., Hamedani, S. S., Yasin, N. M., \& Omar, N. A. (2014). Brand personality moderating effect on relationship between website quality and online trust: Malaysian online environment context. Asian Social Science, 10(11), 210.

Kiran, P., \& Vasantha, S. (2015). Review Article-Exploring the Impact of Online Reviews on Purchase Intentions of Customers. American International Journal of Research in Humanities, Arts and Social Sciences, 15(169), 211-215. 
Kotler, P., \& Amstrong, G. (2012). Prinsip-prinsip Pemasaran. Edisi 12 Jilid 1. Jakarta: Erlangga.

Kotler, P., \& Keller, K. L. (2013). Manajemen Pemasaran. Edisi 13 Jilid 1. Jakarta: Erlangga.

Lukito, S., \& Ikhsan, R. (2020). Repurchase intention in e-commerce merchants: Practical evidence from college students. Management Science Letters, 10(13), 3089-3096.

Marco, R., \& Ningrum, B. T. P. (2017). Analisis Sistem Informasi E-marketplace Pada Usaha Kecil Menengah (UKM) Kerajinan Bambu Dusun Brajan. Jurnal Ilmiah DASI, 18(2), 48-53.

Moriarty, S., Mitchell, N., \& William,W. (2017). Advertising. Jakarta: Kencana.

Mudambi, S. M., \& Schuff, D. (2010). Research note: What makes a helpful online review? A study of customer reviews on Amazon. com. MIS quarterly, 34(1), 185-200, 34(1).

Obiedat, R. (2013). Impact of Online consumer reviews on Buying Intention of Consumers in UK: Need for Cognition as the Moderating Role. International Journal of Advanced Corporate Learning (IJAC), 6(2), 16.

Octavia, D., \& Tamerlane, A. (2017). The Influence of Website Quality on Online Purchase Intentions on Agoda.Com with E-Trust as a Mediator. Binus Business Review, 8(1), 9.

Putra, A. (2017). Pengaruh Iklan Dan Kepercayaan Merek Terhadap Minat Beli Konsumen (Studi Pada Texas Chicken Pekanbaru). JOM FISIP, 4(1), 1-11.

Rachmadhania, N., \& Pangestuti, E. (2017). Pengaruh Efektivitas Iklan Online Terhadap Minat Berkunjung. Jurnal Administrasi Bisnis (JAB), 46(1), 210-217.

Sadgotra, W. Y., \& Saputra, E. H. (2013). Perancangan Online Marketplace Untuk Usaha Kecil Dan Menengah (Ukm) Di Kabupaten Purworejo. Jurnal Ilmiah DASI, 14(04), 54-58.

Setiawaty, N. A. (2017). Pengaruh Iklan, Citra Merek, Dan Kepercayaan Merek Terhadap Minat Beli Konsumen Smartphone Samsung Galaxy Series (Studi Kasus Mahasiswa/I Universitas Gunadarma, Depok). Jurnal Ekonomi Bisnis, 22(1), 4756.

Shahnaz, N. B. F., \& Wahyono, W. (2016). Faktor Yang Mempengaruhi Minat Beli Konsumen Di Toko Online. Management Analysis Journal, 5(4).

Sondakh, L. J., Saerang, D. P. E., \& Rumokoy, F. S. (2016). The impact of online costumer review and celebrity. Jurnal Berkala Ilmiah Efisiensi, 16(4), 296-306.

Tjiptono, F. (2014). Pemasaran Jasa: Prinsip, Penerapan dan Penelitian. Yogyakarta: Andi.

Zourikalatehsamad, N., Payambarpour, S. A., Alwashali, I., \& Abdolkarimi, Z. (2015). The Impact of Online Advertising on Consumer Purchase Behavior Based on Malaysian Organization. International Journal of Economics and Management Engineering, 9, 3424-3429.

Elevenia www.elevenia.co.id

Local Consumer Review 2016 www.brightlocal.com

Peta E-commerce Indonesia 2018 www.iprice.co.id

Tempat belanja online favorit www.sharingvision.com

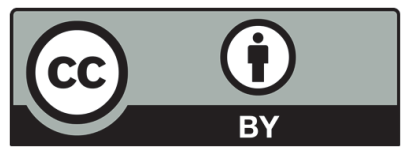

(C) 2020 by the authors; licensee Growing Science, Canada. This is an open access article distributed under the terms and conditions of the Creative Commons Attribution (CC-BY) license (http://creativecommons.org/licenses/by/4.0/). 